\title{
PosFAUUSP 52
}

\section{THE DEBATE ON THE WORK AND PROFESSIONAL PRACTICE OF THE BRAZILIAN ARCHITECT-URBANIST}

\author{
BRUNO CESAR EUPHRASIO DE MELLO \\ Departamento de Urbanismo, Faculdade de Arquitetura, Universidade \\ Federal do Rio Grande do Sul (UFRGS) - Rua Sarmento Leite, 320. Porto \\ Alegre - RS. Brasil. CEP 90050-170. Telefone: (51) 3308-3116 \\ https://orcid.org/0000-0003-1694-157X \\ brunocesaremello@ufrgs.br
}

\section{EUGENIA AUMOND KUHN}

Departamento de Urbanismo, Faculdade de Arquitetura, Universidade Federal do Rio Grande do Sul (UFRGS) - Rua Sarmento Leite, 320. Porto Alegre - RS. Brasil. CEP 90050-170. Telefone: (51) 3308-3116

https://orcid.org/0000-0002-0203-8382

eugenia.kuhn@ufrgs.br

\section{GEISA ZANINI RORATO}

Departamento de Urbanismo, Faculdade de Arquitetura, Universidade Federal do Rio Grande do Sul (UFRGS) - Rua Sarmento Leite, 320. Porto Alegre - RS. Brasil. CEP 90050-170. Telefone: (51) 3308-3116 https://orcid.org/0000-0001-5010-3591 geisa.rorato@ufrgs.br

\section{ABSTRACT}

This article presents the results of an exploratory survey of the literature on labor and the architect and urban planner professional practice, as well a small sample of the most recent debate on the issue carried out by the category in Brazil and in the world. It is noticed that the theme has gained relevance in discussions within the scope of class organization; however, this does not correspond to greater attention from scientific research or academic debate, considering that the existing texts are scattered and do not always focus on work and the exercise of its duties.

KEYWORDS: Work. Professional Practice. Architect and Urban Planner. New Work Morphology.
Received: 01/07/2021

Accepted: 02/12/2021

\section{RESUMO}

Este artigo apresenta os resultados do levantamento exploratório da literatura sobre o trabalho e o exercício profissional do arquiteto e urbanista, bem como uma pequena amostra do debate mais recente sobre a questão realizado pela categoria no Brasil e no mundo. Percebese que o tema tem ganhado relevância nas discussões no âmbito da organização da classe; entretanto, a isso não corresponde uma maior da pesquisa científica ou do debate acadêmico, já que os textos existentes são dispersos e nem sempre tomam como centro de sua atenção o trabalho e o exercício de suas atribuições.

PALAVRAS-CHAVE: Trabalho. Exercício Profissional. Arquiteto e Urbanista. Nova Morfologia do Trabalho. 


\section{INTRODUCTION}

La arquitectura es una de las profesiones más admiradas. Tanto es así, que más de un chofer de taxi me ha confiado con orgullo que ostenta un diploma de arquitecto (BUNGE, 1998).

On July 13, 2017, Federal Law No. 13,467 was enacted, which amended the Consolidation of Labor Laws (CLT), "to adapt the legislation to new labor relations" (BRASIL, 2017). In Brazil, the "labor reform" was the subject of intense controversy and wide debate. On the one hand, its defenders (the business community) argued that it would "modernize" labor relations, adapting them to the new times of capitalism in the era of technological-digital machinery. On the other hand, its critics (the unions) affirmed that it would legitimize all the precarious conditions to which workers were subjected, removing rights, weakening ties, in short, reducing the social protection system.

The movement to transform labor relations has been a topic debated since the 1980s. Since then, researchers have come to maintain that wage earning - and the working class - would disappear ${ }^{1}$. In contrast to this perspective, Antunes (2005, 2011, 2018) believes that work has not become virtual, nor is it on the way to disappear, but has just undergone mutations. It adopted a new morphology. Thus, capital needs less and less stable and protected labor, requiring it to be more and more partial, outsourced, subcontracted, deregulated, informal, in short, precarious. The new CLT reform would be just the most current expression of this phenomenon.

Architects and urban planners ${ }^{2}$ participate in this same process. According to (2015),

It is not uncommon for the Architects Union to receive complaints from companies and offices that circumvent labor legislation. There are reports of work without a formal contract, absence of a contract, illegal use of the selfemployed person's payment receipt, negligible corporate participation, payment of fees below the minimum professional salary, outsourcing, pejotization, etc. (MELLO, 2015).

In addition to these new forms of relationship between capital and labor, there is evidence (SHIMBO, 2010; ARANTES, 2012) that, at present, the Albertian architéctus - the construction intellectual who, due to his/her design knowledge, should command the other actors involved in architectural production - rarely occupies this leading position in the civil construction process. The construction of buildings and cities is today subjected to the logic of power and the social division of labor, in which the architéctus, contrary to what this word supposes due to its etymology (arkhi, the first, which is ahead; and tektonikos, of the construction), today he/she often plays the role of a subordinate designer.

Shimbo's research (2010) gives an example of the subordinate condition that architects are subjected to in large construction companies. The standardization of construction products (standardization that aims to reduce the diversity of solutions, materials and technical details used to maximize profit) places the architect in the role of the outsourced or subcontracted, who must adopt solutions preconceived by others. In the case reported by Shimbo (2010), even when the architect is an employee of the company, he/she is already far from the stages of creative design.

If, for Marx (2013 [1867], p. 255-256), what would distinguish the worst architect from the best bee was the fact that the first had the project in mind before building it; now, the designer of buildings and cities no longer foresees the end of the process. Those

\footnotetext{
${ }^{1}$ Antunes $(2005,2011)$ quotes, for example, André Gorz, Claus Offe, Habermas, Dominique Méda, Robert Kurz, among others.

${ }^{2}$ For the sake of textual conciseness, hereinafter we will refer to the architect and urban planner only as an architect.
} 
who dominate capital and hire the workforce for preestablished tasks have already given it. Thus, there is a gap between the architect and what, at least in the collective imagination, would correspond to a central characteristic of his/her craft: the creative dimension.

Arantes (2012) recognizes that, without "participating in the decisions taken a priori that make up the project, most professionals design fragments of the product" (ARANTES, 2012, p. 130). Therefore, only "chief architects" or "process leaders" would dominate the articulated totality of piecemeal tasks. Only they would have the complete idea of the developed merchandise.

In addition, the automated "digital drawing board" increased the mobility of projects and, consequently, of the teams put in action to carry out technical drawings. Virtual work has even created "CAD monkeys" (ARANTES, 2012), young architects who sell their workforce as outsourced designers of portions of technical products, managed by distant offices. The introduction of CAD software also increased capital gains linked to civil construction. According to Arantes (2012, p. 144): "In offices, computer-aided design promotes time savings and increased productivity."

This phenomenon of the digital age, which promises, initially, the possibility of mutual collaboration, interconnection and reduction of distances, but which ends up, finally, promoting unprotected and poorly paid work, has been called "uberization". Therefore, as can be seen, the architect's activity also participates in this new organization of relations between capital and labor.

Given the situation outlined above, some questions need to be answered: For architects, have changes in legislation "modernized" employer-employee relationships or are they legitimizing a movement of precariousness towards them? What activities do they really carry out in their daily lives?

Based on these issues, it seems necessary to understand in greater depth the field of work and the exercise of the duties of the Brazilian architect. Thus, this article presents the debate on the theme from two spaces: the first, academic-scientific, through an exploratory survey of the literature about the professional performance of the architect in Brazil (search for dissertations, theses, books and articles, in addition to research on the Scielo and Scopus databases and in the annals of the $\mathrm{V}$ and VI Meetings of the National Association for Research and Graduate Studies in Architecture and Urbanism [ENANPARQ]); the second, from class entities and entities for the organization of the category, presenting a small sample of national and foreign initiatives to denounce the precariousness of labor relations and the claim for rights and better working conditions.

\section{WORK AND ITS NEW MORPHOLOGY}

Since antiquity, work has been evoked, positively or negatively, as a relevant theme of social life. In Hesiod (2013 [700 BC?], p. 51), "work is no insult, inaction, an insult". In Ovídio (2017 [8 AD]), the golden age of the world was one in which the land, "which was not touched by a hoe or torn by a plowshare, spontaneously produced everything". He had represented earthly paradise as a place where its man would be unnecessary.

In the industrial age, Marx (2013 [1867], p. 120) asserted that, "as a creator of use values, as useful work, work is thus a condition of man's existence, independent of all social forms, eternal natural need for mediation of the metabolism between man and nature". It would therefore be a necessary condition for human life. However, under the logic of capital, the worker does not recognize it as externalizing himself/herself. The relationship between him/ her and his/her production is, therefore, one of strangeness. For this reason, "his/her strangeness is evident here [in a way] so pure that, as soon as there is no physical or other coercion, he shies away from work like a plague" (MARX, 2010 [1932], p. 83). Work has always oscillated: "as an expression of life and degradation, creation and unhappiness, vital activity and slavery, social happiness and servitude" (ANTUNES, 2005, p. 11). 
With regard to work in the capitalist system, its organization was guided, throughout the 20th century, basically by three systems: Taylorist, Fordist and Toyotist. Frederick Winslow Taylor proposed the Taylorist system at the turn of the 19th to the 20th century. It presupposed the recognition that "the productive capacity of a worker with average experience was always greater than his 'real' production in the company" (PINTO, 2010, p. 25). The solution found by Taylor to reduce this gap between productive capacity and effective production was to establish a standardization of "the one best ways' to perform each work activity" (PINTO, 2010, p.31), which would be passed on to employees as standards. This "scientific" management of production was guided by the following practical elements: a) study of time; b) numerous and functional leadership; c) standardization of instruments for each type of service; d) the need for a planning section; e) instruction sheets for workers, among other aspects. The difference between the Taylorist system and those that preceded it is the fact that "all this complex analysis and planning that involves [the work] is, after its implementation, in charge of the company's management, only in charge of it" (PINTO, 2010, p. 31).

The Fordist system, proposed by Henry Ford, was based, above all, on the standardization of products that, manufactured on an immense scale (for mass consumers), would have their production costs reduced. The novelty introduced by Ford, however, was not only in imagining the possibility of instilling in his contemporaries the predisposition for mass consumption. His innovation occurred in the series production line: "the placement of the work object in an automatic mechanism that runs through all the productive phases, successively, from the first transformation of the raw material to the final stage" (PINTO, 2010, p. 35). Along this line, the activities necessary for production were distributed among fixed workers at their posts, each responsible for tasks of the utmost simplicity, increasing the specialization of the activity. In the Fordist system, "it is the automatic speed of the serial line (...) that imposes on the worker (...) his condition of willingness to work, establishing, within increasingly narrow time limits, the 'best way' to work" (PINTO, 2010, p. 38).

The Taylorist/Fordist system expanded over the two world wars over the central and peripheral capitalist economies. It was hegemonic until the 1970s, when the Toyotist system of work organization began to spread. This model, developed at the Toyota Motor Company, in Japan, since the 1950s, carried out a profound productive reorganization. This production system was based on "a faster production and delivery methodology than the others, associated precisely with the maintenance of a 'lean' and 'flexible' company"' (PINTO, 2010, p. 46). This system - justin-time - was based on deverticalization, automation, subcontracting, requiring a multipurpose workforce, order control, inventory management, the possibility of producing differentiated products, among other aspects.

According to Antunes (2005, 2009, 2011), one of the results of this productive restructuring that took place in the early 1970s was the constitution of a new morphology - or new polysemy - of work. It was sought, in the period, to recover the accumulation pattern lost with the cycles of strikes and social struggles of the end of the 1960s. This phenomenon came to Brazil in the 1990s, with the neoliberal governments of Fernando Collor de Mello and Fernando Henrique Cardoso.

Antunes, as already mentioned, recognizing these changes in the administration of labor that occurred in the 20th century, opposes the hypothesis of the "end of work". He supports the thesis of the renewal of the wage society, which, following the process of Toyotist productive restructuring, tends to deregulate and make labor management more flexible. Thus, capital would need less and less stable work, requiring it to be partial, unprotected, precarious, particular demands of the digital age and of the lean company. In presenting the more general aspects of this new morphology, Antunes (2005) shows that, in addition to urban and rural wage earners, modern capitalist 
society demands the work of a large contingent of outsourced, subcontracted, part-time, temporary workers, among other existing forms of flexibility in the capital-labor relationship.

For this author, in the 21 st century, flexibilization must be understood as 'freedom of the company' to dismiss without penalties, when production and sales decrease; freedom, always for the company, to manipulate the workday according to its convenience, changing the hours and characteristics of the work (by shift, schedule, part-time, flexible hours, excessive overtime, etc.); possibility of paying lower real wages than those required by parity, among many other ways of reducing workers' rights and social protection (ANTUNES, 2009).

Another current expression of job insecurity is the phenomenon of "uberization" (SLEE, 2017) or "platform cooperativism" (SCHOLZ, 2016). New digital technologies - applications and web sharing platforms - have created the opportunity to expand the collaboration and sharing market. Applications like Uber (platform that intends to replace taxis) and Airbnb (platform that intends to replace hotels) emerged with the promise of constituting itself in a virtual space of equity, cooperation and sustainability. However, the sharing economy is, according to Slee (2017), a movement for the deregulation of labor relations and higher income concentration.

These applications transfer the costs and responsibilities for operating the business to its users, releasing themselves from local legal requirements, such as tax collection, operating fees, formalization of economic activity with regulatory agencies. Finally, "uberization" does not mean building a world of collaboration, but of intensifying deregulation and precariousness of relationships.

This is the debate that this article takes as a backdropthat of productive restructuring, the new morphology of work, the incorporation of digital platforms as mediators of labor relations.

\section{THE ACADEMIC DEBATE}

The research sought to recognize, from the framework outlined earlier, how the work of the architect was taken as an issue in the scientific-academic context. Here we present the result of two searches: i) for theses, dissertations, books and articles, trying to constitute a first approximation to the state of the art on the subject; ii) on the Scielo and Scopus databases and in the annals of the V and VI Meetings of the National Association for Research and Graduate Studies in Architecture and Urbanism (ENANPARQ), which took place in the years 2016 and 2018.

We describe below the result of the first search, recognizing that it does not comprehend the totality of the researched universe. The search period has been extended, bringing together texts that cover the period between 1984 and 2020. Next, we will approach each work.

Bicca's book (1984) The architect, the mask and the face analyzes the production of architecture from the division between intellectual and manual activity, taking as the center of interest the role of the architect (personification of intellectual work) in his relationship with the construction worker (personification of manual labor). His study is based on Marxian work and in categories such as alienation, social division of labor, fetishism, among others. However, he does not focus his attention on the architect as an employee, nor does he discuss phenomena that were not on the agenda in the 1980s, such as the precariousness of work relationships linked to digital platforms or its new morphology.

Silva's (1997) thesis, Profession, Knowledge \& Ideology in Architecture, on the other hand, assesses the origin and development of the architect's imagery based on three categories of analysis, including the profession. The author takes as sources historical, theoretical and/or doctrinal texts from the field of Architecture. The thesis reveals, based on this documentation, how architects see themselves and represent themselves. It also reveals the extent to which this "self-built" imaginary is reflected in the architect's praxis. Silva's thesis deals 
with this profession's imaginary about itself, and not about work - employment, workload, salary, exposure to occupational diseases, etc. Nor does it pay attention to the role played by these professionals, for example, in the construction industry

Segnini (2002), in turn, in the thesis The professional practice of the architect under discussion, reflects on the practice based on the relationship between the product of his/her making - the project, mediation between art and technique - and the labor market. The research defends that the existing tension between art, technique and market, originated in the Renaissance, is aggravated in the present, moment of the diffusion of informatics and of globalization. His sources are testimonials and interviews collected from 206 architects selected between 1985 and 2000 from the AU Magazine. From these experiences and the imagery revealed by them, the author shows how and why they make architecture. However, he does not address the capital-labor disputes that occur in the productive space.

Shimbo's thesis (2010), Social housing, market housing: the confluence between the State, construction companies and financial capital, also refers to the work of architects. However, as the central discussion of her research is the confluence between the State, the real estate market and financial capital in the production of social housing, she does so in a brief way. The architect, as already mentioned, plays the role of worker hired or subcontracted by an outsourced office, often in a precarious way. Even when he/she is an employee of the company, he/she is already far from the stages of creative design. The standardization of products (building layouts, technical construction details, etc.), previously established by the company, ends up limiting the search for alternative solutions. The architect thus only repeats a productive "gesture" predefined by the buyer of the workforce.

Whittaker's article (2011), Perspectives and challenges for the young architect in Brazil. What is the role of the profession?, addresses the problem of narrowing the professional field. For him, the specialized magazines and the university present a limited idea of what it means to be successful in the career. In them, there is a certain "deification of authorial architecture with genius talent", which would reduce students' work prospects and present as a unique alternative of success competing in a world of stars of Architecture. Such an attitude, consciously or unconsciously, would reduce the possibilities of exploiting the totality of his/her attributions. In view of this situation, it would be necessary to pay attention also to the "less showy, less evident and less celebrated" face of Architecture, "but whose importance is fundamental to remove the profession from the complex impasse in which it finds itself". The author does not criticize the "high standard" authorial production. He questions, rather, the idea of success linked solely to it. Whittaker presents an instigating way to explain the current market in Architecture. However, he limits his investigation to editions of specialized magazines and assumptions about teaching.

The book by Arantes (2012), Architecture in the digitalfinancial era: drawing, construction site and form income, already mentioned, touches on the theme of work in some moments. Arantes refers to the gigantic teams of international offices - the example mentioned is that of the Englishman Norman Foster's office, which already employed 1,300 architects in the elaboration of about 200 simultaneous projects. At the same time, the activity performed by the majority of these young architects in these large companies is that of CAD designers for a portion of the project. This distances them from a full understanding of the final product, something only available to senior leaders.

The article by Mello (2015), Employment in Architecture and Urbanism and the new morphology of work: Notes from the experience of Rio Grande do Sul, places the theme work at the center of the debate. The article initially addresses the incompatibility of two simultaneous and seemingly contradictory phenomena: on the one hand, the economic growth of the construction industry from 2009 on, and on the other, unemployment and informality in the working relationships of architects. It reflects on the work of these professionals based on 
the notion of "new morphology of work", by Antunes, and "decent work", by the International Labor Organization (ILO). It suggests, in the end, the need for architects to recognize themselves as proletarians.

The Santiago's dissertation (2019), Inventing the opposingspring that resists: reflections on the architect's work in times of precariousness, builds an understanding of the salaried architect's situation, based on texts published by entities representing the category, news in the media and, mainly, application of questionnaires. Despite the small cut of the research, the author recognizes that the data just outlined are an expression of a phenomenon that affects the performance of a greater number of architects. The text puts at the heart of the discussion the precariousness and the new modalities of the capital-labor relationship.

The article by Wilderom and Arantes (2020), Architecture of distance: what the pandemic can reveal about the teaching of Architecture and Urbanism, proposes a reflection on higher education from the new forms of relationship imposed by social isolation, the result of the pandemic Covid-19. However, it also refers to the working relationships of architects as university professors. According to the text, the pandemic has aggravated a process whose characteristics had been outlining itself for some time: the dizzying growth of undergraduate courses in Architecture and Urbanism; the proportional reduction in the number of public courses compared to private ones; the decrease in the Financing Fund for Higher Education Students (FIES) contracts since the economic crisis deepened in 2014; the growth of remote or distance learning courses, the expansion of distance learning businesses. According to Wilderom and Arantes, teachers, in the distance learning age, “also become 'info-proletarian' (...), but without the labor protection that once characterized the industrial proletariat" (WILDEROM, ARANTES, 2020 , n.p.). And they complement that, in the process of " distance learning" or "Uberization of work", the teacher "metamorphosed in an educational App has to make use of his home and equipment, attending online and being monitored in real time content, attendance, productivity - as a deliverer of information" (WILDEROM, ARANTES, 2020, n.p.). This is a text that addresses the architect worker in a specific activity, that of a teacher.

To complement this initial survey, we conducted, as already mentioned, a search on the Scielo and Scopus databases and in the annals of the V and VI ENANPARQ. Below, we will see the criteria and results of this investigation.

For searching the Scielo and Scopus databases, the following protocol was adopted: formulation of the research question (What debate has been held on the work and professional practice of Brazilian architects?), definition of terms and search strategy, selection of studies based on criteria for inclusion and exclusion of articles, presentation of results (SAMPAIO, MACINI, 2007). Table 1 represents the bases, terms, fields, results and dates of the consultation.

\begin{tabular}{|c|c|c|c|c|}
\hline Database & Terms & Fields & Results & Date \\
\hline \multirow[t]{3}{*}{ Scielo } & Trabalh* AND Arquitet* AND Brasil* & All indexes & 213 & Dec. 11,2020 \\
\hline & Profiss* AND Arquitet* AND Brasil* & All indexes & 45 & Dec. 11,2020 \\
\hline & Exercício AND Profiss* AND Arquitet* AND Brasil* & All indexes & 2 & Dec. 11,2020 \\
\hline \multirow[t]{3}{*}{ Scopus } & Trabalh* AND Arquitet* AND Brasil* & $\begin{array}{c}\text { Article title, Abstract, } \\
\text { Keywords }\end{array}$ & 4 & Dec. 11,2020 \\
\hline & Profiss* AND Arquitet* AND Brasil* & $\begin{array}{c}\text { Article title, Abstract, } \\
\text { Keywords }\end{array}$ & 0 & Dec. 11,2020 \\
\hline & Exercício AND Profiss* AND Arquitet* AND Brasil* & $\begin{array}{c}\text { Article title, Abstract, } \\
\text { Keywords }\end{array}$ & 0 & Dec. 11,2020 \\
\hline
\end{tabular}

Table 1: Search terms used in the Scielo and Scopus databases. Source: authors. 
The terms defined for the search were trabalh* (work, worker), exercício profiss* (profession, professional), arquitet* (architect, architecture), Brasil* (Brazil, Brazilian). The strategy included, in the Scielo database, all indexes and, in the Scopus, the title of the article, abstract and keywords, always without time restriction. The research was carried out on December 11, 2020. The number of articles found was as follows: Scielo database - 260 articles; Scopus database -4 articles.

From this pre-selection, the abstracts of the 264 articles surveyed were read. The criterion for inclusion or exclusion of articles in the documentary corpus was the approximation in relation to the theme. Of that total, only three treat it to some extent. They reflect on professional practice relating it to technical assistance for social housing (Portuguese acronym: ATHIS). In Socio-spatial groups or whom technical advisory practice serves, Kapp (2018) discusses ATHIS practices in Architecture and Urbanism and Planning based on the concept of socio-spatial group. In $W$ e, the architects of the homeless, Lopes (2018) assesses the performance in contexts of interlocution between architects and social movements, typical of ATHIS, and finally suggests that the profession should be reinvented, taking on new content and changing the way it operates. The text From the critique of the building site to self-management: Sérgio Ferro, Usina and the self-managed joint efforts in São Paulo, Brazil, by Amaral (2020), investigates the work methodology of the Usina (office with extensive experience intechnical assistance in Architecture to social movements), its design and decision processes. It takes as a basis for analysis the concepts of collective worker and criticism of the building site, by Sérgio Ferro. None of them refers to the new morphology of work or the exercise of duties in the context of changing the labor legislation, thus distancing itself from the topic that interests us.

In the annals of the V and VI ENANPARQ, the search terms and strategy were similar, namely: trabalh* (work, worker), exercício profiss* (profession, professional), arquitet* (architect, architecture), Brasil* (Brazil, Brazilian) in the titles, abstracts and keywords of the articles. From this initial selection, a reading of the abstracts was made to verify the relationship with the topic that interests us. The research in the annals of the IV ENANPARQ, 2016, did not find any results. In V ENANPARQ, 2018, in turn, only two articles were found, presented at the thematic tables/sessions.

The article by Caser (2018), Gender discrimination in architecture: the professional field from the perspective of the female architect, addresses the gender discrimination faced by female architects in their daily work. It takes the state of Espírito Santo as the locus of the study and, through interviews, characterizes more recurrent situations of discrimination fees, invisibility, macho culture, stereotypes or marginalization. This study focuses, of course, on the issue of women in their workplace. However, it does not extrapolate it.

The article by Silva, Monte and Leite (2018), Training and professional performance: an overview of architecture and design in northeastern Brazil, aims to outline a perspective of training and performance in Architecture, as well as in Product Design, in the northeast of Brazil. It investigates what is in common in these courses, such as the profile of graduates and their performance in the labor market The article took as sources of data schools, councils and registries of companies. It is a text that is not concerned with the exercise of duties or with the new modalities of capital-labor relationship. For this reason, the research distances itself from the problem we have proposed.

It is noticed that, even expanding the search, the literature on the work of the architect in Brazil is scarce and that the theme needs a more dedicated look. Existing texts do not always focus on work and the exercise of professional duties. In addition, contemporary phenomena - the introduction of the "digital drawing board", the new media and their impact on the "drawing site" ARANTES, 2012), the "uberization" (SLEE, 2017), the "platform cooperativism", the new morphology of work (ANTUNES, 2005, 2011, 2018) - have been little investigated. 


\section{PROFESSIONAL DEBATE}

In addition to the literature review, it is also necessary to present the debate held by entities representing the category on the issue, not only in Brazil, but also foreign organizational initiatives to denounce the precariousness of labor relations and claim for rights and better working conditions. We will mention few examples, but they seem to be enough to point out how this is an emerging theme.

In Brazil, the Union of Architects in the State of Rio Grande do Sul (SAERGS) promoted, in the months of October and November 2020, the "SAERGS Forum in the world of work", a series of lives that discussed issues such as "Precariousness of work for architects"3, "New morphologies of work in Architecture and urbanism"4, "The misery of teaching AU in the age of precariousness" ${ }^{\text {. The }}$ The National Federation of Architects and Urban Planners (FNA), in turn, from May 2020, also promoted virtual conferences on topics such as "Where are the rights that were here? Dilemmas of work in Brazil""; "Minimum Professional Wage: the right and duty of all architects and urban planners"7, "Moral harassment in labor relations: health and legal issues" ${ }^{8}$. In other words, class entities - notably union entities - have discussed contemporary challenges related to the transformation of employer-employee relationships.

In addition to the concern at the national level, in other countries architects have also denounced the precarious employment links and demanded better conditions and rights. We will cite just two examples: Portugal and the countries of the United Kingdom.

In Portugal, the Workers' Movement in Architecture (MTA $)^{9}$ started its activities in February 2019. It assumes itself as a mobilizer for all workers in the sector: "architects enrolled in their professional order, interns in the course of their training, designers, model makers and other specialist technicians in the field" (MOVIMENTO DOS TRABALHADORES EM ARQUITECTURA, 2019, p. 5). After several meetings, its manifesto was approved on November 9 of the same year. According to it, the notion "that work in architecture is predominantly developed by the self-employed, independent professional who carries out his/her projects is, today, out of step with reality" (MOVIMENTO DOS TRABALHADORES EM ARQUITECTURA, 2019, p. 2). The intention of the movement is:

"[...] to end all forms of precarious, irregular or illegal work, claiming that equal work corresponds to equal rights, each job corresponds to an effective contract and dignified conditions that value the indispensable contribution of all workers in architecture" (MOVIMENTO DOS TRABALHADORES EM ARQUITECTURA, 2019, p. 4).

In the United Kingdom, young architects formalized, in 2019, their union as a section (Section of Architectural Workers - SAW) da United Voices

\footnotetext{
${ }^{1}$ Available at: https://www.youtube.com/watch?v=TQrOt8fYLpc.

${ }^{2}$ Available at: https://www.youtube.com/watch?v=qpA9TsTTTe8.

${ }^{3}$ Available at: https://www.youtube.com/watch?v $=8 \mathrm{qfZn} 50$ Aqsg\&t=16s.

${ }^{4}$ Available at: https://www.youtube.com/watch?v=Ak_wOxJ_j84.

${ }^{5}$ Available at: https://www.youtube.com/watch?v=nS-PEmRGKTI.

${ }^{6}$ Available at: https://www.youtube.com/watch?v=XwlTElTqpxA.

${ }^{7}$ It is possible to access information about the MTA through the website http://www.movimento-mta.pt/.

${ }^{8}$ Available at: https://www.youtube.com/watch?v=XwlTElTqpxA.

${ }^{9}$ It is possible to access information about the MTA through the website http://www.movimento-mta.pt/.
} 
of the World (UVW) ${ }^{10}$, the latter, a union entity similar to the Brazilian union centrals. The SAW intends to represent a wide range of workers in Architecture: assistants, model makers, BIM technician $^{11}$, administrative employees, architects, landscapers, students, researchers, receptionists, interior designers, freelancers, janitors, individual entrepreneurs, among others. The union organizes itself in branches in the workplace and demands the observance of already established rights, such as those that rule the work hours, the payment of overtime, the payment of minimum wage, among others. Finally, it fights against overwork, insufficient wages, unstable jobs, sexual and moral harassment, in addition to welcoming immigrants, the LGBT population, etc.

These few examples suggest how what Antunes $(2005,2011,2018)$ calls a new morphology of work has been put on the agenda in the category's debates and has moved architects around the world to oppose this reality in an organized way.

\section{FINAL CONSIDERATIONS}

As we mentioned at the beginning of this article, a series of phenomena has transformed labor relations. Its impacts have also been felt in the field of Architecture and Urbanism. It was possible to verify that the literature on the theme "the work of the architect in Brazil" is still little recurrent. Existing texts are scattered and do not always focus on the work and the exercise of professional duties. Furthermore, contemporary phenomena - the introduction of the "digital drawing board", the new media and their impact on the "drawing site", the "uberization", the "platform cooperativism", the new morphology of work - appear very little in the academic debate There is still plenty of space for research that problematizes the issue in different dimensions, such as working conditions and relationships, activities performed, position occupied in the production chain, among others. It is also noticed, on the other hand, that the theme has gained relevance in the category's discussions in Brazil and in the world. The results of the exploratory survey of the literature on the work of the architect, as well as the small sample of the most recent discussion of the category on the subject in Brazil and in the world reveal a certain asymmetry between the concern of the academic environment and the representative entities about the same object. After all, how to reduce this distance between the academic debate and the concern of class entities?

\section{REFERENCES}

ALVES, G. Trabalho e Subjetividade: o espírito do toyotismo na era do capitalismo manipulatório. São Paulo: Boitempo, 2011.

AMARAL, B. Da crítica do canteiro à autogestão: Sérgio Ferro, Usina e os mutirões autogeridos em São Paulo, Brasil. Finisterra, LV(114), 2020, pp. 141-155.

ANTUNES, R. O privilégio da servidão: o novo proletariado de serviços na era digital. São Paulo: Boitempo, 2018.

ANTUNES R. Adeus ao trabalho?: ensaio sobre as metamorfoses e a centralidade do mundo do trabalho. São Paulo: Cortez, 2011.

ANTUNES R. O trabalho, sua nova morfologia e a era da precarização estrutural. Revista Theomai: Estúdios críticos sobre sociedad y desarollo, n. 19, primeiro semestre de 2009, p. 50-51 http://revista-theomai.unq.edu.ar/ NUMERO19/ArtAntunes.pdf. Accessed on: Jan. 5, 2021.

ANTUNES R. O caracol e sua concha: ensaios sobre a nova morfologia do trabalho. São Paulo: Boitempo, 2005.

ARANTES, P.F. Arquitetura na era digital-financeira: desenho, canteiro e renda da forma. São Paulo: Editora 34, 2012.

\footnotetext{
${ }^{10}$ Information about the UVW - Section of Architectural Workers can be accessed at https://www.uvwunion.org.uk/en/sectors/architectural-workers/.

${ }^{11}$ Building Information Modeling (BIM) is a digital platform that allows information and parameters to be added to the modeling of a building.
} 
BICCA, P. Arquiteto a máscara e a face. São Paulo: Projeto Editores Associados, 1984.

BUNGE, M. Una disciplina poliédrica. La Nacion. Available at: http://www.lanacion.com.ar/107696-unadisciplina-poliedrica. Accessed on: Jan. 5, 2021.

CASER, K.C. Discriminação de gênero em arquitetura: o campo profissional pela perspectiva da mulher arquiteta. Salvador: Anais do V ENANPARQ, 2016, p. 642-665.

HESÍODO. O trabalho e os dias. São Paulo: Hedra, 2013.

KAPP, S. Grupos sócio-espaciais ou a quem serve a assessoria técnica. Revista Brasileira de Estudos Urbanos e Regionais, São Paulo, v.20, n.2, p. 221-236, mai.-ago. 2018. DOI: https://doi.org/10.22296/23171529.2018v20n2p221

LOPES, J.M.A. Nós, os arquitetos dos sem-teto. Revista Brasileira de Estudos Urbanos e Regionais, São Paulo, v.20, n.2, p. 237-253, Mai.-ago. 2018. DOI: https://doi. org/10.22296/2317-1529.2018v20n2p237

MELLO, B.C.E. Emprego em arquitetura e urbanismo e nova morfologia do trabalho. Notas a partir da experiência do Rio Grande do Sul. Arquitextos, São Paulo, ano 15, n. 178.02, Vitruvius, mar. 2015. Available at: http://www. vitruvius.com.br/revistas/read/arquitextos/15.178/5493. Accessed on: Jan. 5, 2021.

MARX, K. O Capital: crítica da economia política: Livro I: o processo de produção do capital. São Paulo: Boitempo, 2013.

MARX, K. Manuscritos econômico-filosóficos. São Paulo: Boitempo, 2010.

MOVIMENTO DOS TRABALHADORES EM ARQUITECTURA. Manifesto do Movimento dos Trabalhadores em Arquitectura, 09 nov. 2019. Available at: http://www.movimento-mta.pt/documentos/20191109Manifesto_MTA.pdf. Accessed on: Jan. 5, 2021.

OVÍDIO. Metamorfoses. São Paulo: Editora 34, 2017.

PINTO, G.A. A organização do trabalho no século XX: taylorismo, fordismo e toyotismo. São Paulo: Expressão Popular, 2010.

SAMPAIO, R.F.; MANCINI, M.C.; Estudos de Revisão Sistemática: um guia para síntese criteriosa da evidência científica. Revista Brasileira de Fisioterapia, São Carlos, v.11, n.1, p. 83-89, jan./fev.2007.

SANTIAGO, A.D.C. Inventando a contra-mola que resiste: reflexões sobre o trabalho do arquiteto em tempos de precarização. Dissertação (mestrado) Programa de PósGraduação em Arquitetura e Urbanismo da Universidade Federal Fluminense, Escola de Arquitetura e Urbanismo: Niterói, 2019.

SCHOLZ, T. Cooperativismo de plataforma: contestando a economia do compartilhamento corporativa. São Paulo: Fundação Rosa Luxemburgo; Elefante; Autonomia Literária, 2016.

SEGNINI, F. A prática profissional do arquiteto em discussão. Tese (doutorado) Faculdade de Arquitetura e Urbanismo, USP: São Paulo, 2002.

SHIMBO, L.Z. Habitação social, habitação de mercado: a confluência entre Estado, empresas construtoras e capital financeiro. Tese (doutorado) Programa de Pós-Graduação em Teoria e História da Arquitetura e do Urbanismo, Escola de Engenharia de São Carlos da Universidade de São Paulo: São Carlos, 2010.

SILVA, E. Profissão, conhecimento \& ideologia na Arquitetura. Tese (doutorado) Programa de Pósgraduação em sociologia. Porto Alegre: UFRGS, 1997.

SILVA, H.A.; MONTE, A.C.; LEITE, I.F.B. Formação e atuação profissional: panorama geral da arquitetura e do design no nordeste brasileiro. Salvador: Anais do V ENANPARQ, 2016, p.794-808.

SLEE, T. Uberização: a nova onda do trabalho precarizado. São Paulo: Elefante, 2017.

WHITAKER, J.S. Perspectivas e desafios para o jovem arquiteto no Brasil. Qual o papel da profissão? Arquitextos, São Paulo, ano 12, n. 133.07, Vitruvius, jul. 2011. Available at: http://www.vitruvius.com.br/ revistas $/ \mathrm{read} /$ arquitextos/12.133/3950. Accessed on: Jan. 5, 2021.

WILDEROM, M.; ARANTES, P.F. Arquiteturas da distância: o que a pandemia pode revelar sobre o ensino de Arquitetura e Urbanismo. ArchDaily Brasil. 02 ago. 2020. Available at: https://www.archdaily.com.br/ br/944738/arquiteturas-da-distancia-o-que-a-pandemiapode-revelar-sobre-o-ensino-de-arquitetura-e-urbanismo. Accessed on: Jan. 5, 2021. 
ZARDO, P.; MUSSI, A.Q.SILVA, J.L. Tecnologias digitais no processo de projeto contemporâneo: potencialidades e desafios à profissão e à academia. Ambiente Construído, Porto Alegre, v. 20, n. 2, p. 425-440, abr./jun. 2020.

ACKNOWLEDGMENTS: To the Conselho Nacional de Desenvolvimento Científico e Tecnológico (CNPq) for funding the research that gave rise to this article.

The research had financial support from the Conselho Nacional de Desenvolvimento Científico e Tecnológico (CNPq), case 436471/2018-3 / Call MCTIC/CNPq N ${ }^{\circ}$ $28 / 2018$. 